\title{
A Voice for National Interests
}

As readers of College and Research $\mathrm{Li}$ braries know, the American Library Association proposes a campaign for a Library Development Fund, with a view to caring for the interests of libraries at the nation's capital. The bearing of this upon the position and work of college and reference libraries is brought out in the following statement.

$\mathrm{A}^{\mathrm{s}}$

$S$ ISOLATED INDIVIDUALS, the members of a profession have great difficulty in making their influence felt in public matters. With the development of group consciousness and group organization and the erection of machinery of contact with other groups, they become more important social factors.

While professional associations lack the financial resources of business groups and while they lack the numbers of labor and agricultural associations, they possess assets which are of prime importance in public affairs today: namely, the technical knowledge of their members and strategic places their members fill in modern society. Yet the importance of librarians to modern society seems to be equaled only by their modesty and timidity and, all too often, by their frustration. They are charged with care of that great collective brain of modern technological civilization, the printed page. It is the corporate memory of things past and the great medium of communication and integration of thought for the present and future. But by their very selfless devotion to it, librarians sometimes fail to save it from those who would destroy it or from those who, from ignorance or indifference, would starve it.

There is evidence that we as a profession are beginning to know and appreciate compelling economic, political, and social facts. The American Library Association plan to establish a Washington representative is a most welcome sign that the professional association is seeking to keep in step with the times and that the zeal to greater service which moved the founders in 1876 is glowing anew.

Although the national Constitution does not so provide, it is increasingly apparent that there are two levels or bases of representation in our government. The first and highest is that which always has existed, that of duly elected officials, broadly representing parties and localities. The second basis of representation is that of groups of citizens with common interests. While each individual citizen still has the ancient right of petition, in effect it has been devaluated by the tremendous increase in the number of citizens and by the complexity and interrelationships of each citizen's needs and desires. It is only through the group and with expert testimony, effectively presented, that the modern citizen can be heard.

As a profession, we librarians are noted for loyalty and devotion to the public welfare. Our satisfaction is in service, and no amount of increase in sales and consumption will be reflected in increased profits. We are peculiarly fitted to raise our voice in Washington for the good of all.

The plan to have an established represen- 
tative in Washington is by no means an experiment. Certainly it is not new to other professional associations. Many of the groups to whom we are closest in interest have permanent headquarters there and wield important influence, among them being the National Education Association, the American Council on Education, the American Council of Learned Societies, and the American Association of University Professors. The American Library Association has done this sort of thing with great success in one field, that of library relations with Latin America, and recently, to some extent, in connection with other international relations. Our representatives have been accepted as experts and have rendered important services to the government. There has been no question as to their sincerity and the value of their contribution nor of the purposes of the Association which sponsored their efforts. We have both the right and the duty to have a voice in other affairs of even greater importance.

It is true that we have spoken on other points and other issues and occasionally our voice has been heard. But the record is not completely satisfactory. Perhaps those who have listened to our representatives have measured our convictions as to what was said by our failure to provide constant, continual, and completely effective support. Without reflecting on the excellent work which has been done on a part-time basis, doubtless more could be accomplished with a regularly assigned representative who was in a position to learn his way around, to get acquainted, to be always available for questions, and to practice that watchful waiting which is essential in gaining results.

Among the issues with which college, university, and research librarians have recently been concerned, or may soon in the future be concerned, the following may be cited. The conclusion is obvious that concentrated effort is necessary and that the A.L.A. campaign deserves fullest support.

We are all interested in securing surplus property; we want to deal directly rather than through brokers in the open market; we certainly don't want to see this material destroyed, as some have proposed. If any governmental aid to college and research libraries is available again, we want to put in our claim. As the programs for returning veterans develop, college and university librarians wish proper recognition for the services they render; this support finally came for the Army Specialized Training Program, but we were worried by the delay.

We are disturbed by the increasing limitations and difficulties in the distribution of government documents. Our primary concern is not self-interest in making our acquisition work easier but our fundamental responsibility in a democracy to see that documents are properly available. We are glad that the Library of Congress catalog is at last being printed but we are distressed that so useful and important a tool could not be produced and distributed by the same liberal hand that has broadcast so many thousands of tons of paper bearing print of relatively little consequence. In harsh but reasonable words someone has compared the cost of this set with the cost of a comparable volume such as the Army Medical Library catalog and called the difference a $\operatorname{tax}$ on the dwindling book funds of our libraries.

We are faced with continued difficulties in the way of purchase and importation of foreign books. If we are to continue to serve our college and university students and faculties, we must insist that these channels be cleared as soon as possible.

When we seek to make our voice heard in Washington we are not looking for Santa Claus. We are only expressing our belief in the vital importance of our work. 